\title{
ACCELERATED AGING OF Piptadenia moniliformis (BENTH.) SEEDS ${ }^{1}$
}

\author{
GUTIERRES SILVA MEDEIROS AQUINO ${ }^{2}$, CLARISSE PEREIRA BENEDITO ${ }^{2 *}$, KLEANE TARGINO OLIVEIRA \\ PEREIRA $^{2}$, PAULO CÉSAR DA SILVA SANTOS ${ }^{2}$, JÉSSICA CHRISTIE DANTAS DE OLIVEIRA ${ }^{2}$
}

\begin{abstract}
The accelerated aging test consists of evaluating the vigor of the seeds under conditions of high temperature and humidity, with the purpose of identifying the physiological quality of lots with similar germination. The objective of this study was to evaluate the efficiency of the accelerated aging test for classifying seed lots of $P$. moniliformis at different levels of vigor. Initially, the seed lots were assessed by means of seedling emergence, life velocity index, shoot length and root length, total dry mass of seedlings and determination of water content, before and after each period of aging. The experimental design for the whole world was based on a $3 \times 4$ factorial scheme (three seed lots and four periods of 24, 48, 72 and $96 \mathrm{~h}$ duration), with separate evaluations at temperatures of $38{ }^{\circ} \mathrm{C}$ and $41{ }^{\circ} \mathrm{C}$. The accelerated aging test conducted at a temperature of $41{ }^{\circ} \mathrm{C}$ for $24 \mathrm{~h}$ was a more suitable combination for separating batches of $P$. moniliformis according to different levels of vigour, and made it possible to obtain results similar to the classification of lots in relation to the initial quality.
\end{abstract}

Keywords: Fabaceae. Vigor. Forest seeds.

\section{ENVELHECIMENTO ACELERADO EM SEMENTES DE Piptadenia moniliformis (BENTH.)}

RESUMO - O teste de envelhecimento acelerado consiste em avaliar o vigor das sementes em condições de elevada temperatura e umidade, com a finalidade de identificar diferenças na qualidade fisiológica de lotes com germinação semelhante. Dessa forma, objetivou-se avaliar a eficiência do teste de envelhecimento acelerado para classificar os lotes de sementes de $P$. moniliformis em diferentes níveis de vigor. Inicialmente os lotes de sementes foram avaliados por meio da emergência de plântulas, índice de velocidade de emergência, comprimento da parte aérea e da raiz, além da massa seca total de plântulas, além da determinação do grau de umidade, antes e após cada período de envelhecimento das sementes. O delineamento experimental foi o inteiramente casualizado, em esquema fatorial 3 x 4 (três lotes de sementes e quatro períodos de 24, 48, 72 e 96 horas), e avaliado separadamente nas temperaturas de 38 e $41{ }^{\circ} \mathrm{C}$. O teste de envelhecimento acelerado conduzido sob a temperatura de $41{ }^{\circ} \mathrm{C}$ durante 24 horas é a combinação mais adequada para separar os lotes de $P$. moniliformis em diferentes níveis de vigor, pois possibilitou a obtenção de resultados semelhantes à classificação dos lotes em relação à qualidade inicial.

Palavras-chave: Fabaceae. Vigor. Sementes florestais.

\footnotetext{
${ }^{*}$ Corresponding author

${ }^{1}$ Received for publication in $05 / 10 / 2017$; accepted in 10/05/2017.

Paper extracted from the scientific initiation work of the first author.

${ }^{2}$ Department of Agronomics and Forests Sciences, Universidade Federal Rural do Semi-Árido, Mossoró, RN, Brazil; gutierressilva@hotmail.com - ORCID: 0000-0003-4492-5550, clarisse@ufersa.edu.br - ORCID: 0000-0002-2846-1162, kleane_rn@hotmail.com - ORCID: 0000-0002-3863-9606, paulocesaref@hotmail.com - ORCID: 0000-0001-7428-4091, chris_jessica2011@hotmail.com - ORCID: 0000-0002-4659-1286.
} 


\section{INTRODUCTION}

Piptadenia moniliformis (Benth.) belongs to the Fabaceae family, known in the Brazilian Northeast as catanduva, and occurs in the Caatinga biome, often in the states of Maranhão, Piauí, Ceará and Bahia. It is a pioneer species, rustic and fast growing, indicated for heterogeneous reforestation for preservation purposes. Due to its small size, the wood is used in small construction works, light carpentry, tool cables, firewood and charcoal (LORENZI, 2002).

Study of the handling aspects of $P$. moniliformis seeds is needed, since this input constitutes the main starting point for obtaining seedlings of satisfactory quantity and quality (LEÃO et al., 2015). According to these authors, it is essential that different segments of the forest sector attend to these requirements these requirements are essential to attend to the different segments of the forest sector, especially with regard to seed quality, which are evaluated through the germination test that provides security in the commercialization of these.

However, the germination test is frequently insufficient for decision making with regard to selecting batches for storage or for immediate use. In addition, forest seed technologists still face difficulties in assessing seed quality and establishing production techniques' establishing seed quality and production techniques, due to the large biomorphological variation in fruits and seeds from the different species (GONÇALVES et al., 2009; MARTINS; LAGO; SALES, 2009). Therefore, knowledge of the quality of a seed lot depends on the availability of accurate methods that generate reliable results (MARCOS-FILHO, 2015).

Several tests exist to determine the vigor of the seeds, with the objective of identifying important differences in the physiological potential of seeds, especially in those with similar germinative power. Among the vigor tests, accelerated aging has been notable for being able to provide information with a high degree of consistency, identifying more vigorous batches of seeds and with greater capacity to maintain their viability during storage (AMARO et al., 2014).

The accelerated aging test consists of exposing the seeds to conditions of high humidity and temperature, assuming that seeds of lower quality deteriorate faster than the more vigorous ones, and therefore showing a decrease in germination after stress. This test is widely used to evaluate the vigor of seeds of several species, especially those of vegetables, since within a few days it is possible to obtain consistent results regarding the quality of the lot. However, each species presents different responses depending on the temperature and the time of exposure of the seeds to the stress conditions (MARCOS-FILHO, 2015).

There are few studies on this subject in forest seeds, although some researchers have obtained promising results, such as Guedes et al. (2009) with seeds of Erythrina velutina, Flavio and Paula (2010) with Dictyoloma vandellianum A. Juss., Pereira and Martins Filho (2010) with Solanum sessiliflorum, Guedes et al. (2011) with Dalbergia nigra, Guedes, Alves and Oliveira (2013) with Chorisia glaziovii, and Lima et al. (2014) with Poincianella pyramidades.

Based on the efficiency of the accelerated aging test with other forest species, the test was evaluated for classifying seed lots of $P$. moniliformis according to vigor.

\section{MATERIAL AND METHODS}

The experiments were carried out with three lots of $P$. moniliformis seeds as follows: Lot 1 were collected in August 2014 from the city of Areia Branca - RN (4 ${ }^{\circ} 56^{\prime} 52^{\prime}$ 'S and $\left.37^{\circ} 7^{\prime} 28^{\prime \prime} \mathrm{W}\right)$; Lot 2 were collected in Mossoró - RN (5 ${ }^{\circ} 11$ '17' 'S and $37^{\circ} 20^{\prime} 39$ " W) in August 2014; and Lot 3 ( $5^{\circ} 03$ ' $37^{\prime \prime S}$ and $37^{\circ} 23^{\prime} 50^{\prime \prime} \mathrm{S}$ ). The seed lots were conditioned in a PET bottle and stored in a cold and dry chamber $\left(17^{\circ} \mathrm{C}\right.$ and $40 \%$ relative humidity) until analysis.

To verify the initial quality of the seed lots, several evaluations were carried out as follows. a) Degree of humidity: the greenhouse method was used at $105 \pm 3{ }^{\circ} \mathrm{C}$ for $24 \mathrm{~h}$ (BRASIL, 2009), with two sub-samples of approximately 50 seeds in each lot and the results expressed as a percentage (wet basis). This determination was performed before and after the accelerated aging test. b) Emergence of seedlings: conducted in a greenhouse with four subsamples of 25 seeds per batch. The seeds were sowed in plastic trays $(28 \times 20 \times 7 \mathrm{~cm})$, containing vermiculite substrate of medium grain size, previously sterilized and initially moistened with water equal to twice the dry substrate weight, as recommended by Brasil (2013). Irrigations were performed manually on a daily basis. The evaluation occurred at 10 days after sowing, and the results expressed as the percentage emergence of normal seedlings. c) Emergency speed index: daily counts of the number of normal seedlings, using the formula of Maguire (1962). d) Length of aerial part and root of seedlings: the length of the aerial part of the seedlings was measured, using a ruler graduated in millimeters, from the insertion of the neck to the apex of the apical bud. The length of the root was measured from the insertion of the colon to the end of the main root. Results were expressed in $\mathrm{cm}$. e) Total seedling dry mass: normal seedlings were packed in paper bags (kraft type) and placed in an oven with forced air circulation at $65 \pm 3{ }^{\circ} \mathrm{C}$ until constant weight was achieved and then weighed.

The accelerated aging test was conducted with four subsamples each containing 25 seeds. 
Plastic boxes $\left(\right.$ Gerbox $\left.{ }^{\circledR}\right)(11.5 \times 11.5 \times 3.5 \mathrm{~cm})$ were used, individually adapted as mini-chambers, the interior of which was equipped with a metallic screen to support the seeds that were evenly distributed inside. Distilled water $(40 \mathrm{~mL})$ was added to the bottom of each plastic box, providing an environment of $100 \%$ relative humidity. The boxes were capped and placed inside the climatic chamber for aging periods of $24,48,72$ and $96 \mathrm{~h}$ duration, in temperatures of $38^{\circ} \mathrm{C}$ and $41^{\circ} \mathrm{C}$. At the end of each period, the seeds were submitted to the germination test on substrate between sand at $30{ }^{\circ} \mathrm{C}$ in a Biochemical Oxygen Demand (B.O.D) chamber, whose evaluation occurred seven days after the installation (BRASIL, 2013), since the interpretation is performed only through a count (MARCOS-FILHO, 2015). For the purpose of monitoring the test, the water content of the seeds was determined before and after the aging periods.

The experimental design was a completely randomized design, with four replicates of 25 seeds per lot and using a $3 \times 4$ factorial scheme (three lots and four exposure periods), evaluating each temperature separately. The data were submitted to analysis of variance and the means were compared using the Tukey test at 5\% probability.

\section{RESULTS AND DISCUSSION}

The results of the initial quality of seed lots of $P$. moniliformis were high, with seedling emergence values higher than $80 \%$ (Table 1). Analysis of the rate of emergence and the length of the aerial part, it was observed a superior and equal performance between lots 1 and 2, although lot 2 did not differ from lot 3. With regard to root length and total dry mass of seedlings, lot 1 was higher than the other lots (Table 1).

Table 1. Characterization of initial seed quality of Piptadenia moniliformis Benth. by the emergence (E), emergence speed index (ESI), shoot length (SL), root length (RL) and total dry mass of seedlings (TDMS).

\begin{tabular}{cccccc}
\hline Lot & E $(\%)$ & ESI & SL $(\mathrm{cm})$ & RL $(\mathrm{cm})$ & TDMS $(\mathrm{g})$ \\
\hline 1 & $90 \mathrm{a}$ & $5.8 \mathrm{a}$ & $2.1 \mathrm{a}$ & $8.7 \mathrm{a}$ & $0.29 \mathrm{a}$ \\
2 & $83 \mathrm{a}$ & $4.9 \mathrm{ab}$ & $2.4 \mathrm{ab}$ & $6.9 \mathrm{~b}$ & $0.24 \mathrm{~b}$ \\
3 & $85 \mathrm{a}$ & $4.6 \mathrm{~b}$ & $2.8 \mathrm{~b}$ & $6.4 \mathrm{~b}$ & $0.23 \mathrm{~b}$ \\
\hline C.V $(\%)$ & 10.8 & 11.59 & 7.73 & 8.86 & 6.94 \\
\hline
\end{tabular}

CV: coefficient of variation.

Averages followed by the same letter in the columns do not statistically differ among themselves by Tukey's test $(p<0.05)$.

The water content of the three seed lots before aging was approximately $10 \%$, with a variation of less than $1 \%$ between the lots. This fact indicates that the test was in the range recommended for its accomplishment because, according to Marcos-Filho (2015), it must be ensured that the test is installed with samples whose water content does not vary by more than 2.0 percentage points. According to the same author, the wettest seeds are more sensitive to the test conditions and therefore are subject to more intense deterioration. After aging, it was verified that the values for humidity increased gradually as a function of the periods of exposure, reaching close to $50 \%$ for the $96-\mathrm{h}$ period and the temperature of $38^{\circ} \mathrm{C}$ (Table 2).

Table 2. Water content before and after the accelerated aging test in Piptadenia moniliformis Benth. using temperatures of $38^{\circ} \mathrm{C}$ and $41^{\circ} \mathrm{C}$, and for periods of $24,48,72$ and $96 \mathrm{~h}$.

\begin{tabular}{|c|c|c|c|c|c|}
\hline \multicolumn{6}{|c|}{ Water content $(\%)$} \\
\hline \multirow[t]{2}{*}{ Lot } & \multirow[t]{2}{*}{ Initial } & \multicolumn{4}{|c|}{$38^{\circ} \mathrm{C}$} \\
\hline & & $24 \mathrm{~h}$ & $48 \mathrm{~h}$ & $72 \mathrm{~h}$ & $96 \mathrm{~h}$ \\
\hline 1 & 9.9 & 31.1 & 40.8 & 46.4 & 48.7 \\
\hline 2 & 9.7 & 33.7 & 41.7 & 48.6 & 50.8 \\
\hline \multirow[t]{3}{*}{3} & 9.6 & 33.5 & 40.1 & 47.2 & 48.9 \\
\hline & & \multicolumn{4}{|c|}{$41^{\circ} \mathrm{C}$} \\
\hline & & $24 \mathrm{~h}$ & $48 \mathrm{~h}$ & $72 \mathrm{~h}$ & $96 \mathrm{~h}$ \\
\hline 1 & 9.9 & 34.0 & 42.5 & 43.2 & 46.9 \\
\hline 2 & 9.7 & 35.6 & 44.0 & 47.7 & 48.2 \\
\hline 3 & 9.6 & 33.9 & 42.7 & 43.8 & 46.7 \\
\hline
\end{tabular}

Rev. Caatinga, Mossoró, v. 31, n. 3, p. 681 - 686, jul. - set., 2018 
Evaluating the physiological quality of seeds of Dalbergia nigra (Vell.) Fr. All. by means of accelerated aging, Guedes et al. (2011) demonstrated that the seeds absorbed a significant amount of water, reaching values higher than $30 \%$ with temperatures of $41{ }^{\circ} \mathrm{C}$ and $45{ }^{\circ} \mathrm{C}$. Carvalho and Nakagawa (2012) emphasized that the increase in water content favors the increase of the temperature in the seed, due to the activation of the respiratory process and greater activity of microorganisms. These were observed in the present study, mainly with a temperature of $41{ }^{\circ} \mathrm{C}$ and longer periods of aging.

The difference in water uptake by seeds exposed to accelerated aging is an important aspect to be considered, since when exposed to a humid atmosphere there are variations in the water content of these seeds (TUNES et al., 2011). These changes can cause variations in the intensity of deterioration, because the higher the water content of the seeds, the higher the sensitivity to high temperature and relative humidity of the air that occurs during the test (LIMA et al., 2011). The intensity of water absorption after accelerated aging varies greatly among forest species, and one of the factors that may be involved is the degree of impermeability of the integument.

By means of the accelerated aging test, the stratification of the lots was verified at the two evaluated temperatures. At $38^{\circ} \mathrm{C}$, lot 1 did not show a reduction in germination with increasing exposure duration, remaining with values equal to or above $90 \%$. Lots 2 and 3 showed a reduction in germination with increasing period of exposure of the seeds to aging, whereas lots 2 and 3, after $96 \mathrm{~h}$, had germination values of $69 \%$ and $28 \%$, respectively. In the $24-\mathrm{h}$ period, germination was above $70 \%$ in all lots. However, after $48 \mathrm{~h}$, there was a clear difference between the lots evaluated, with lots 1, 2 and 3 being classified as of superior, middle and lower quality, respectively. This classification became more evident as the period of exposure increased; with $96 \mathrm{~h}$ of aging, there was a drastic reduction in germination of lot $3(28 \%)$, while lot 1 maintained germination at $90 \%$ and lot 2 at $69 \%$ (Table 3).

Table 3. Germination (\%) after the accelerated aging test in Piptadenia moniliformis Benth. using temperatures of $38{ }^{\circ} \mathrm{C}$ and $41{ }^{\circ} \mathrm{C}$, and for periods of $24,48,72$ and $96 \mathrm{~h}$.

\begin{tabular}{ccccc}
\hline & & $38^{\circ} \mathrm{C}$ & & $96 \mathrm{~h}$ \\
\hline Lot & $24 \mathrm{~h}$ & $48 \mathrm{~h}$ & $72 \mathrm{~h}$ & $90 \mathrm{aA}$ \\
\hline 1 & $96 \mathrm{aA}$ & $93 \mathrm{aA}$ & $94 \mathrm{aA}$ & $69 \mathrm{bB}$ \\
2 & $88 \mathrm{aA}$ & $76 \mathrm{bAB}$ & $75 \mathrm{bAB}$ & $28 \mathrm{cB}$ \\
\hline & $72 \mathrm{bA}$ & $59 \mathrm{cA}$ & $57 \mathrm{cA}$ & $84 \mathrm{aA}$ \\
\hline 1 & & $41^{\circ} \mathrm{C}$ & $84 \mathrm{aA}$ & $71 \mathrm{aA}$ \\
2 & $99 \mathrm{aA}$ & $86 \mathrm{aA}$ & $72 \mathrm{aA}$ & $22 \mathrm{bB}$ \\
\hline
\end{tabular}

Averages followed by the same lowercase letter in the column and uppercase letter in the row did not differ from each other by Tukey's test $(\mathrm{p}<0.05)$.

At $41{ }^{\circ} \mathrm{C}$, it was also possible to classify the lots at different levels of physiological quality. Lots 1 and 2 did not differ from each other with all exposure periods. However, lot 3 showed inferior performance with all exposure periods, reaching $22 \%$ germination after $96 \mathrm{~h}$. The stressful conditions of accelerated aging lead to a gradual reduction in the viability and vigor of the seeds, probably due to a higher consumption of reserves due to accelerated metabolic activity (cellular respiration) under these conditions and, consequently, a lower seedling emergence rate (GUEDES; ALVES; OLIVEIRA, 2013).

Although lot 3 showed a high emergence rate in the initial quality, it differed from lots 1 and 2 after accelerated aging. This result may be related to the history of this lot, since its seeds 'had been stored for three years. Thus, when they underwent conditions of stress, there was confirmation of a decrease physiological potential which had occurred during storage. This is because, generally, the more vigorous seeds (freshly harvested) retain more capacity to produce normal seedlings, consequently they present higher germination rates, even after being submitted to the accelerated aging, whereas those of low vigor are characterized by greater reduction in viability and being less able to cope with adverse storage and field conditions (CARNEIRO; NOGUEIRA; ABREU, 2004).

Research has sought to elucidate the mechanisms that determine seed deterioration when exposed to high temperature and humidity conditions. In addition to the loss of cellular compartmentalization, the disintegration of the membrane system promotes uncontrolled metabolism and water and solutes changes between cells and the external environment, determining the viability of the seed (MARCOS-FILHO, 1999).

Seeds of several forest species may present different behaviors when subjected to aging periods and temperatures. Guedes et al. (2011), for example, failed to detect differences in quality levels between 
seed lots of $D$. nigra aged at $41{ }^{\circ} \mathrm{C}$ for $24 \mathrm{~h}$, with significant results only after $72 \mathrm{~h}$. However, for seeds of $P$. pyramidalis, the use of a temperature of $41{ }^{\circ} \mathrm{C}$ and a 24 -h period of exposure in traditional accelerated aging was enough to evaluate the physiological potential of seeds from different matrices (LIMA et al., 2014). With seeds of cubiu (S. sessiliflorum), Pereira and Martins Filho (2010) also found that aging at $41{ }^{\circ} \mathrm{C}$ for $72 \mathrm{~h}$ or $96 \mathrm{~h}$ was more efficient for differentiation of lots in terms of physiological quality.

Although the information provided by the accelerated aging test is of great importance, it is unlikely that only one parameter will be able to predict the behavior of the lots under the most varied environmental conditions (MARCOS-FILHO, 1999). Thus, it is generally verified that the use of the traditional accelerated aging test allowed the results to be obtained similar to the classification of lots in relation to the initial quality, a fact observed at a temperature of $41{ }^{\circ} \mathrm{C}$ for $24 \mathrm{~h}$. Despite the importance of and the demand for information on seeds of forest species, particularly the Caatinga biome, research studies concerning seed vigor are still incipient.

\section{CONCLUSIONS}

The accelerated aging test conducted at a temperature of $41^{\circ} \mathrm{C}$ for $24 \mathrm{~h}$ is the most appropriate combination for separating $P$. moniliformis seed lots with different levels of vigor, since it enabled results to be obtained that were similar to the classification of the lots according to their initial quality.

\section{REFERENCES}

AMARO, H. T. R. et al. Teste de envelhecimento acelerado em sementes de crambe (Crambe abyssinica Hochst), cultivar FMS Brilhante. Revista Ceres, Viçosa, v. 61, n. 2, p. 202-208, 2014.

BRASIL. Ministério da Agricultura, Pecuária e Abastecimento. Regras para análise de sementes. Ministério da Agricultura, Pecuária e Abastecimento. Secretaria de Defesa Agropecuária. Brasília: MAPAACS, 2009. 395 p.

BRASIL. Ministério da Agricultura, Pecuária e Abastecimento. Instruções para análise de sementes de espécies florestais. Brasília: MAPA/ ACS, 2013. 97 p.

CARNEIRO, G. C.; NOGUEIRA, A. C.; ABREU, D. C. A. Influência do envelhecimento acelerado no vigor de sementes de Anadenanthera colubrina (Vellozo). Ciência Florestal, Santa Maria, v. 14, n.
1, p. 85-90, 2004.

CARVALHO, N. M.; NAKAGAWA, J. Sementes: ciência, tecnologia e produção. 5. ed. Jaboticabal, SP: FUNEP, 2012. 590 p.

FLAVIO, J. J. P.; PAULA, R. C. Testes de envelhecimento acelerado e condutividade elétrica em sementes de Dictyoloma vandellianum A. Juss. Scientia Forestalis, Piracicaba, v. 38, n. 87, p. 391399, 2010.

GONÇALVES, E. P. et al. Potencial fisiológico de sementes de mutambo (Guazuma ulmifolia Lam.) em diferentes procedências. Revista Caatinga, Mossoró, v. 22, n. 2, p. 218-222, 2009.

GUEDES, R. G.; ALVES, E. U.; OLIVEIRA, L. S. B. Teste de envelhecimento acelerado em sementes de Chorisia glaziovii (Kuntze) (Malvaceae). Bioscience Journal, Uberlândia, v. 29, n. 2, p. 378 $385,2013$.

GUEDES, R. S. et al. Resposta fisiológica de sementes de Erythrina velutina Willd. ao envelhecimento acelerado. Semina: Ciências Agrárias, Londrina, v. 30, n. 2, p. 323-330, 2009.

GUEDES, R. S. et al. Envelhecimento acelerado na avaliação da qualidade fisiológica de sementes de Dalbergia nigra (Vell.) Fr. All. Semina: Ciências Agrárias, Londrina, v. 32, n. 2, p. 443-450, 2011.

LEÃO, V. M. L. et al. Biometria e diversidade de temperaturas e substratos para a viabilidade de sementes de ipê amarelo. Informativo ABRATES, Londrina, v. 25, n. 1, p. 50-54, 2015.

LIMA, C. B. et al. Germinação e envelhecimento acelerado na análise da qualidade fisiológica de sementes de alfavaca-cravo. Semina: Ciências Agrárias, Londrina, v. 32, n. 3, p. 865-874, 2011.

LIMA, C. R. et al. Qualidade fisiológica de sementes de diferentes árvores matrizes de Poincianella pyramidalis (Tul.) L. P. Queiroz. Revista Ciência Agronômica, Fortaleza, v. 45, n. 2, p. 370-378, 2014.

LORENZI, H. Árvores brasileiras: manual de identificação e cultivo de plantas arbóreas nativas do Brasil. 2. ed. Nova Odessa, SP: Plantarum, 2002. 368 p.

MAGUIRE, J. D. Speed of germination aid in selection and evaluation for seedling and vigour. Crop Science, Madison, v. 2, n. 2, p. 176-177, 1962.

MARCOS-FILHO, J. Teste de envelhecimento acelerado. In: KRZYZANOWSKI, F. C.; VIEIRA, 
R. D.; FRANÇA NETO, J. B. (Eds.). Vigor de sementes: conceitos e testes. Londrina: ABRATES, 1999. v. 1, cap. 3. p. 1-24.

MARCOS-FILHO, J. Fisiologia de sementes de plantas cultivadas. 2. ed. Londrina, PR: ABRATES, 2015. $660 \mathrm{p}$.

MARTINS, L.; LAGO, A. A.; SALES, W. R. M. Conservação de sementes de ipê-amarelo [Tabebuia chrysotricha (Mart. Ex DC.) Standl.] em função do teor de água das sementes e da temperatura do armazenamento. Revista Brasileira de Sementes, Lavras, v. 31, n. 2, p. 86-95, 2009.

PEREIRA, M. D.; MARTINS FILHO, S. Envelhecimento acelerado em sementes de cubiu (Solanum sessiliflorum Dunal). Pesquisa Agropecuária Tropical, Goiânia, v. 40, n. 3, p. 251$256,2010$.

TUNES, L. M. et al. Envelhecimento acelerado em sementes de azevém com e sem solução salina e saturada. Ciência Rural, Santa Maria, v. 41, n. 1, p. 33-37, 2011. 